\title{
Improvement in Mathematics Learning Outcomes in Fraction Operation Material with Grid Square Unit Media
}

\author{
Asha Septianti Nur Rohmah \\ Pelangi Edukasi School, Argomulyo, Salatiga, Indonesia \\ asha.septianti24@gmail.com
}

\begin{abstract}
This research was motivated by MI Ma'arif Kutowinangun fifth grade students who have difficulty in receiving the lessons with materials related to addition and subtraction of various fractions. Especially, when dealing with addition and subtraction of fractions operations with different denominators. This was showed by the results of interviews and observations made by the author. With minimum completeness criteria of 60 , from 14 students of $\mathrm{V}$ class, only nine of them reached the minimum completeness criteria, and the rest have not been able to achieve the minimum completeness criteria.

Based on the above problems, then the author conducted Classroom Action Research (CAR) to determine the improvement of mathematics learning outcomes in fraction operation material with grid square unit media. The research subject was fifth grade students of MI Ma'arif Kutowinangun consisting of 20 students, 11 of them were female and nine of them were male. While, the data collection was obtained through interviews, observation, and evaluation results through written tests which then were analyzed by percentage.

Based on this research, there was improvement of student mathematics learning outcomes in fraction operation with grid square unit media. From 20 students who reached the minimum completeness criteria 60 in the first cycle was 16 students or $80 \%$. Then it increased in the second cycle that all fifth grade students of MI Ma'arif Kutowinangun reached the minimum completeness criteria or $100 \%$.
\end{abstract}

Keywords: Learning Outcomes, Media Grid Square Units 


\section{INTRODUCTION}

Learning will make someone who does not know to know, who cannot be able to be able, and there is a change in behavior on him either directly or indirectly. As Sutikno (2014: 187) states that the learning process is an effort made by someone to be able to obtain a new change. However, many teachers are less aware in changing and improving the learning outcomes of their students. So that there is less expected improvement in learning outcomes.

Mathematics according to Jannah (2011: 17-25) in the beginning is arithmetic or the science of calculating various objects or others. If we look at the Indonesian Dictionary (Kamus Besar Bahasa Indonesia), mathematics is interpreted as the science of numbers, relationships between numbers, and operational procedures used in solving number problems. Mathematics is an exact science and concrete, meaning that mathematics becomes real science that can be applied directly in everyday life, in various forms. So in the application of our daily lives cannot be separated from mathematics.

In regulation of the national education minister (Permendiknas) No. 22 of 2006 concerning content standards, one of the Basic Competencies (Kompetensi Dasar) in Mathematics in the fifth grade of elementary school (SD/ MI) is to add and subtract various forms of fractions. Students experience this material difficulty because students do not understand how to equate the denominator. Either in the operation of fraction addition, as well as fractions subtraction. 
According to Hamalik (1989: 18) suggests that the use of teaching media in the teaching and learning process can stimulate new desires and interests, generate motivation and learning activities stimulus, and even bring psychological effects to students. The use of teaching media will greatly help the effectiveness of the learning process and the delivery of messages and the content of the material to be delivered. Students will more easily absorb new knowledge and be more active in class.

From the results of the interviews with Muniri, as homeroom teacher of the fifth grade of MI Ma'arif Kutowinangun, students had difficulty in receiving lessons with materials related to fraction operations. Especially when dealing with the problems of addition operations and subtraction factions with different denominator. It is proven by the fact that there are still many students who get grades under KKM (Minimum Completion Criteria). Minimum Completion Criteria for the mathematics subjects applied at MI Ma'arif Kutowinangun is 60 . From 14 students of fifth grade, only nine students who have reaches the KKM score and the rest have not been able to reach the KKM score. This means that there are still many students who have not mastered the Fractional Operation material.

Therefore, the need for alternative solutions, including media that are considered suitable for improving learning outcomes in fraction operating materials, is by using media in the form of grid square units. Students will understand the easy way to equalize the denominator, 
Mudarrisa: Jurnal Kajian Pendidikan Islam, Vol. 11, No. 1, 2019

so that they will be able to improve students' mathematics learning outcomes.

Hidayah and Sugiarto in First Workshop of Faculty of Math and Science UNNES, 2004 stated that what was meant by grid square units was teaching aids made of transparent plastic (mica) in the form of square or rectangular lines drawn into square plots. But there is a slight modification by replacing the mica with cardboard/white board. The use of these media in mathematics learning can be done by using colorful markers or mica to distinguish each part of the box that has been used for writing. With the development of the availability of materials at this time, this dotted paper can be made using a board (with a dot using a permanent marker), and the process is done with temporary markers that can be removed (Muhsetyo, et al., 2011: 2.30).

This is what makes the writer feel the need to raise this issue to be a research title, namely: "Improvement in Mathematics Learning Outcomes in Fraction Operation Material with Grid Square Unit Media". Then it is necessary to have action research to obtain empirical data needed to prove that grid square unit media can improve the mathematics learning outcomes in the addition and subtraction of various forms fraction in the fifth grade students at MI Ma'arif Kutowinangun.

\section{METHODS}

This study used Classroom Action Research (action research) carried out through two cycles that contain: cycle I and cycle II. The purpose of this 
study was to improve the mathematics learning outcomes in the addition and subtraction of various forms fraction with grid square unit media. Each cycle was carried out in four stages, namely: planning, acting, observation, and reflecting.

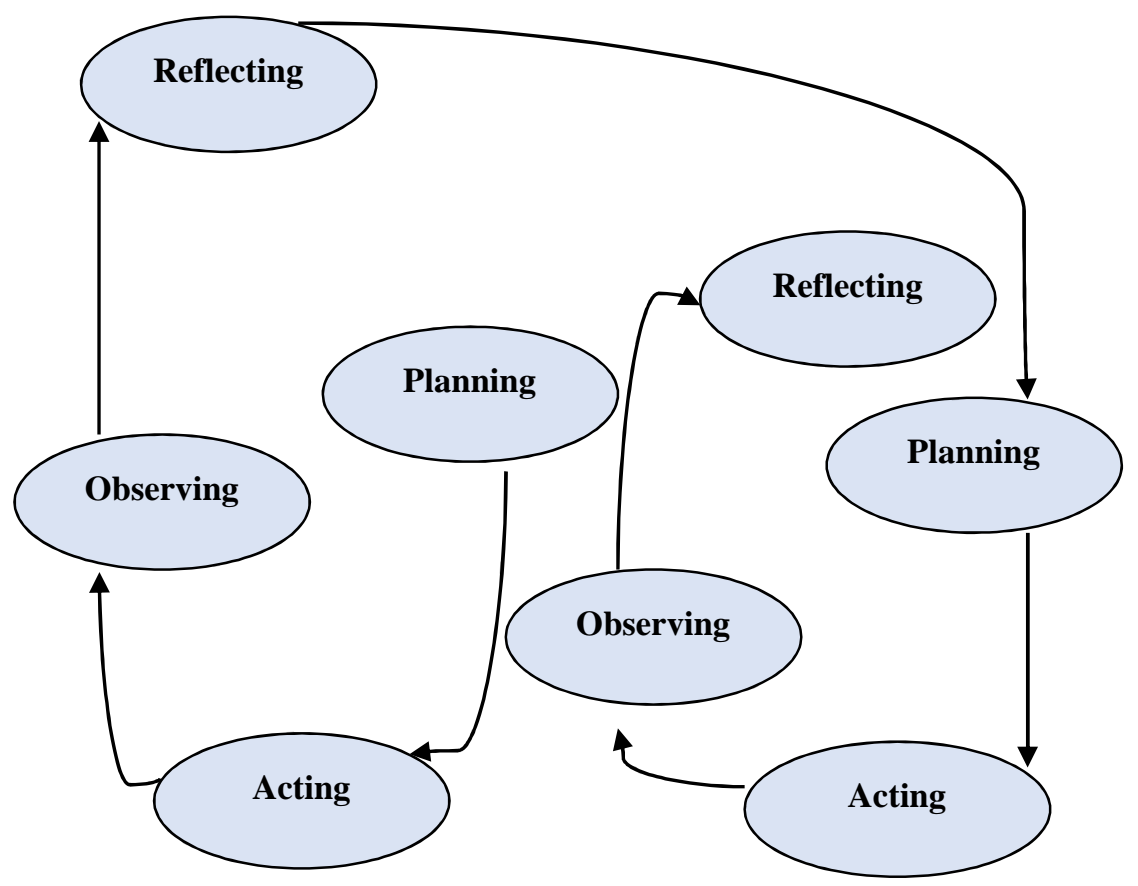

Figure 1. Classroom Action Research Procedure (Elfanany, 2013: 61)

The research subjects in this Classroom Action Research were students in the fifth grade of MI Ma'arif Kutowinangun, 20 students consisting of 11 female students and 9 male students. The research instrument as a data collection tool carried out in this study were: interviews, observation and documentation. A reflective analysis 
used by researcher to determine the action program in the next cycle to detect that this class action research has reached its goal, was data processing formulas by finding the percentage of each activity (Djamarah, 2000: 226).

$$
-\quad \%=
$$

Note:

$\mathrm{F} \quad=$ Frequency in minutes.

$\mathrm{N}=$ Total number of activities in minutes.

$\mathrm{P} \quad=$ Amount of value in percent (relative value).

\section{DISCUSSION}

\section{Pre Cycle}

Before conducting the research, the pre-cycle stage was carried out by conducting interviews and observations on August 24th, 2015 and December 11th, 2015. Based on the narrative of the fifth grade homeroom teacher of MI Ma'arif Kutowinangun, students had difficulty in receiving lessons with material related to addition and reduction in various forms of fractions. Especially when dealing with the problems of addition operations and subtraction of different denominators (Tosto et al., 2016:3). Many students are still incomprehensive when they faced with the addition and subtraction of fractions. Of the 14 students, only 9 students 
completed the KKM (Minimum Completion Criteria) score which was equal to 60.

Furthermore, observations were made to determine the condition and circumstance of the students at the time of following the learning and the way the fifth grade homeroom teacher of MI Ma'arif Kutowinangun managed and delivered learning. It was found that students at the time of learning lacked attention to the teacher in explaining the material. Many students were even joking around, talked with friends, and others. The teacher also never used media in delivering the material. So, the teacher only gave the formulas.

\section{Cycle I}

In providing student learning outcomes, researchers refer to the achievement of student Minimum Completion Criteria (KKM) targets. Minimum Completion Criteria for mathematics subjects applied in MI Ma'arif Kutowinangun is 60. If the value obtained by students is equal to or greater than 60 , then the student is declared "Completed." If the student's score is still below the Minimum Completion Criteria the student is declared "Incompleted".

In the first cycle, which was held on January 11, 2016, data collection was carried out by using a written test as an instrument for collecting data. The data obtained from the results of the tests performed in Table 1. 
Mudarrisa: Jurnal Kajian Pendidikan Islam, Vol. 11, No. 1, 2019

Table 1. Value of Student Cycle I Learning Outcomes

\begin{tabular}{cccc}
\hline No. & Student's name & Value & Completeness \\
\hline 1 & $\mathrm{~A}$ & 80 & (Completed) \\
\hline 2 & $\mathrm{~B}$ & 70 & (Completed) \\
\hline 3 & $\mathrm{C}$ & 60 & (Completed) \\
\hline 4 & $\mathrm{D}$ & 60 & (Completed) \\
\hline 5 & $\mathrm{E}$ & 50 & (Incomplete) \\
\hline 6 & $\mathrm{~F}$ & 80 & (Completed) \\
\hline 7 & $\mathrm{G}$ & 90 & (Completed) \\
\hline 8 & $\mathrm{H}$ & 70 & (Completed) \\
\hline 9 & $\mathrm{I}$ & 60 & (Completed) \\
\hline 10 & $\mathrm{~J}$ & 60 & (Completed) \\
\hline 11 & $\mathrm{~K}$ & 50 & (Incomplete) \\
\hline 12 & $\mathrm{~L}$ & 80 & (Completed) \\
\hline 13 & $\mathrm{M}$ & 50 & (Incomplete) \\
\hline 14 & $\mathrm{~N}$ & 70 & (Completed) \\
\hline 15 & $\mathrm{O}$ & 60 & (Completed) \\
\hline 16 & $\mathrm{P}$ & 90 & (Completed) \\
\hline 17 & $\mathrm{Q}$ & 60 & (Completed) \\
\hline 18 & $\mathrm{R}$ & 90 & (Completed) \\
\hline 19 & $\mathrm{~S}$ & 60 & (Completed) \\
\hline 20 & $\mathrm{~T}$ & 40 & (Incomplete) \\
\hline
\end{tabular}

From the data above, it showed that the percentage of students was completed in formula below:

$$
\begin{aligned}
P & =\frac{F}{N} \times 100 \% \\
& =\frac{16}{20} \times 100 \%=80 \%
\end{aligned}
$$

Meanwhile, the percentage of students who did not complete was in formula below:

$$
P=\frac{F}{N} \times 100 \%
$$




$$
=\frac{4}{20} \times 100 \%=20 \%
$$

Based on the analysis above, it was found that students who completed Minimum Completion Criteria 60 in the first cycle, were 16 students or $80 \%$ and those who had not completed were $20 \%$. From the number of fifth grade students of MI Ma'arif Kutowinangun, the average score of the class was 66.5 .

Reflection

After did research in the first cycle, there were several obstacles that need to be considered and made reference to the improvement in the next cycle as follows: The media used was still too new for students. So that, during group discussions students were still confused about choosing fractions of mica that would be paired on square units; some student paid less attention to the material being taught; some student still did not have the courage to ask questions and answer questions.

The lack of student activeness can be seen from the Table 2 that explained some assessment ascpet.

Table 2. Students' Activeness of Cycle I

\begin{tabular}{clcc}
\hline \multirow{2}{*}{ No. } & Assessment Aspect & \multicolumn{2}{c}{ Students Involved } \\
\cline { 3 - 4 } & & Total & $\%$ \\
\hline 1. & Student activeness & 14 & $70 \%$ \\
\hline 2. & Student Attention & 10 & $50 \%$ \\
\hline 3 & Work in group & 15 & $75 \%$ \\
\hline 4 & Answer the question & 7 & $35 \%$
\end{tabular}


Mudarrisa: Jurnal Kajian Pendidikan Islam, Vol. 11, No. 1, 2019

\begin{tabular}{ccccc}
\hline No. & Assessment Aspect & & \multicolumn{2}{c}{ Students Involved } \\
\cline { 3 - 4 } & & & Total & $\%$ \\
\hline 5 & The Accuracy of & 10 & $50 \%$ \\
& Demonstrating Media & &
\end{tabular}

Therefore, the corrective actions that need to be taken to improve the first cycle such as: Henceforth, students should be introduced more deeply with the grid square unit media and the teacher gave directions on how to apply the use of grid square unit media to fractional counting operations; It was best for the teacher to package learning as interesting as possible. So, students would be enthusiastic and wanted to pay attention to the material explained by the teacher and; the teacher encouraged and enticed students to ask questions and answer questions (Demirel \& Caymaz, 2015:10).

\section{Cycle II}

In the cycle II held on January 13rd, 2016, the data collection was done in the same manner as in the first cycle by using a written test as a data collection instrument. The datas were obtained from the results of tests carried out in cycle II were showed in Table 3.

Table 3. Learning Outcomes Result of Student Cycle II

\begin{tabular}{cccc}
\hline No. & Student's name & Value & Completeness \\
\hline 1 & A & 90 & (Completed) \\
\hline 2 & B & 80 & (Completed) \\
\hline 3 & C & 70 & (Completed) \\
\hline 4 & D & 90 & (Completed) \\
\hline 5 & E & 80 & (Completed) \\
\hline 6 & F & 90 & (Completed) \\
\hline 7 & G & 90 & (Completed) \\
\hline
\end{tabular}


Mudarrisa: Jurnal Kajian Pendidikan Islam, Vol. 11, No. 1, 2019

\begin{tabular}{cccc}
\hline No. & Student's name & Value & Completeness \\
\hline 8 & H & 90 & (Completed) \\
\hline 9 & I & 80 & (Completed) \\
\hline 10 & J & 80 & (Completed) \\
\hline 11 & K & 80 & (Completed) \\
\hline 12 & L & 90 & (Completed) \\
\hline 13 & M & 90 & (Completed) \\
\hline 14 & N & 90 & (Completed) \\
\hline 15 & O & 70 & (Completed) \\
\hline 16 & P & 100 & (Completed) \\
\hline 17 & $\mathrm{Q}$ & 100 & (Completed) \\
\hline 18 & $\mathrm{R}$ & 100 & (Completed) \\
\hline 19 & $\mathrm{~S}$ & 80 & (Completed) \\
\hline 20 & $\mathrm{~T}$ & 60 & (Completed) \\
\hline
\end{tabular}

From the data above, it shows that the percentage of students who was completed in formula below:

$$
\begin{aligned}
P & =\frac{P}{N} \times 100 \% \\
& =\frac{20}{20} \times 100 \%=100 \%
\end{aligned}
$$

Meanwhile, the percentage of students who did not complete in formula below:

$$
\begin{aligned}
P & =\frac{F}{N} \times 100 \% \\
& =\frac{0}{20} \times 100 \%=0 \%
\end{aligned}
$$

Based on the analysis above, it was found that the implementation of the second cycle experienced a significant increase and went very well so that it could achieve $100 \%$ completeness. The number of students who completed the Minimum Completion Criteria (KKM) 60 in the first cycle 
Mudarrisa: Jurnal Kajian Pendidikan Islam, Vol. 11, No. 1, 2019

were 16 students or $80 \%$. Furthermore, it increased in the second cycle, all students in fifth grade of MI Ma'arif Kutowinangun who reached the Minimum Completion Criteria (KKM) score were 100\%. With an average value in this second cycle was 85 . Based on this, the $85 \%$ of Minimum Completion Criteria (KKM) can be achieved completely.

Reflection

The implementation of the second cycle has reached the target. Students in the fifth grade of MI Ma'arif Kutowinangun could meet the Minimum Completion Criteria (KKM) in mathematics learning, which was 60, and $85 \%$ of students in the class completed the Class Minimum Completion Criteria. The implementation of research in the second cycle went well and student learning outcomes also increased.

The implementation of the second cycle research was not without constraints. Obstacles certainly existed, but the intensity was very small. So that the implementation of the third cycle of research could meet the Class Minimum Completion Criteria by $85 \%$. These obstacles are found if the students still talked to themselves when the media was distributed for group discussion, but the intensity was only a little and the students' activeness also began to increase as in Table 4 .

Table 4. Students' Activeness of Cycle II

\begin{tabular}{clcc}
\hline \multirow{2}{*}{ No. } & Assessment Aspect & \multicolumn{2}{c}{ Students Involved } \\
\cline { 3 - 4 } & & Total & $\%$ \\
\hline 1 & Student activeness & 17 & $85 \%$ \\
\hline 2 & Student Attention & 13 & $65 \%$
\end{tabular}


Mudarrisa: Jurnal Kajian Pendidikan Islam, Vol. 11, No. 1, 2019

\begin{tabular}{llcc}
\hline \multirow{2}{*}{ No. } & Assessment Aspect & \multicolumn{2}{c}{ Students Involved } \\
\cline { 3 - 4 } & & Total & $\%$ \\
\hline 3 & Work in group & 16 & $80 \%$ \\
\hline $\mathbf{4}$ & Answer the question & 12 & $60 \%$ \\
\hline $\mathbf{5}$ & The Accuracy of & 16 & $80 \%$ \\
& Demonstrating Media & & \\
& &
\end{tabular}

Improvements that must be made in situate students to be willing to listen to what the teacher instructed.

\section{Analysis of Cycle I and II}

Recapitulation of Learning Outcomes

Outcomes data of the student in Cyle I and II proccess were showed in Table 5.

Table 5. Research Result Data for Each Cycle

\begin{tabular}{cccc}
\hline \multirow{2}{*}{\begin{tabular}{c} 
So. Student's Name \\
\cline { 2 - 4 }
\end{tabular}} & \multicolumn{2}{c}{ Research Results Per Cycle } \\
\hline 1 & Cycle I & Cycle II \\
\hline 2 & B & 80 & 90 \\
\hline 3 & C & 70 & 80 \\
\hline 4 & D & 60 & 70 \\
\hline 5 & E & 60 & 90 \\
\hline 6 & F & 50 & 80 \\
\hline 7 & G & 80 & 90 \\
\hline 8 & H & 90 & 90 \\
\hline 9 & I & 70 & 90 \\
\hline 10 & J & 60 & 80 \\
\hline 11 & K & 60 & 80 \\
\hline 12 & L & 50 & 80 \\
\hline 13 & M & 80 & 90 \\
\hline 14 & N & 50 & 90 \\
\hline
\end{tabular}


Mudarrisa: Jurnal Kajian Pendidikan Islam, Vol. 11, No. 1, 2019

\begin{tabular}{cccc}
\hline No. & Student's Name & \multicolumn{2}{c}{ Research Results Per Cycle } \\
\cline { 2 - 4 } & & Cycle I & Cycle II \\
\hline 15 & O & 60 & 70 \\
\hline 16 & P & 90 & 100 \\
\hline 17 & Q & 60 & 100 \\
\hline 18 & R & 90 & 100 \\
\hline 19 & S & 60 & 80 \\
\hline 20 & T & 40 & 60 \\
\hline
\end{tabular}

From the results, it had been conducted there was an increase in learning completeness by two cycles that showed in Table 5 .

Table 6. Recapitulation of Student Learning Outcomes

\begin{tabular}{ccc}
\hline Implementation / Provisions & Cycle I & Cycle II \\
\hline Complete & 16 & 20 \\
\hline Not complete & 4 & -
\end{tabular}

Initial conditions

From the results of interviews and observations could be conducted by researcher on August 24, 2015 and December 11, 2015. The researcher found that the fifth grade students of MI Ma'arif Kutowinangun had difficulty in receiving lessons with material related to addition and subtraction of various forms of fractions. Especially when dealing with the problems of addition operations and subtraction of different denominations. This was because the teacher never uses media in mathematics learning.

Final condition

After learning mathematics in the material of adding and subtracting various forms of fractions by using grid square unit media, students experience the increased learning outcomes. The number of students who 
completed the Minimum Completion Criteria (KKM) 60 in the first cycle was 16 students or $80 \%$ with an average value of 66.5 . Furthermore, it increased in the second cycle that all students in the fifth grade of MI Ma'arif Kutowinangun reached the KKM score were 100\%. With an average value in this second cycle of 85 . Based on this, the $85 \%$ KKM could be achieved completely.

Although in the implementation of this second cycle research still existed a little obstacle, but the intensity was very small. So that the implementation of the second cycle of the research could meet the class KKM of $85 \%$. Students talked to themselves when the media was distributed for group discussion, but the intensity was only a little and the students' activeness also began to increase. This was as self-improvement and reflection for researchers for further learning.

\section{CONCLUSION}

From the results of the research and the discussion in IV chapter, there are improvements of students' mathematics learning outcomes with grid square unit media, proved by the number of students who were 20 to Minimum Completion Criteria (KKM) of 60. In the first cycle, 16 students or $80 \%$ encountered KKM with an average value of 66.5 . Furthermore, increasing in the second cycle, all students in the fifth grade of MI Ma'arif Kutowinangun could reached the KKM score of $100 \%$. With an average value in this second cycle of 85 . So, the amount of $85 \%$ of students KKM was achieved completely. 
Then, it needed more active learning, the willingness to pay attention to the learning and courage to ask, so that learning time will be more efficient. The learning of mathematics using grid square unit media requires sufficient preparation and mastering the teaching material. The time and location of the study needs to be calculated properly.

\section{REFERENCES}

Demirel, M., \& Caymaz, B. (2015). Prospective Science and Primary School Teachers' Self-efficacy Beliefs in Scientific Literacy. Procedia - Social and Behavioral Sciences, 191, 1903-1908.

Hardianti, R. D., Taufiq, M., \& Pamelasari, S. D. (2017). The Development of Alternative Assessment Instrument in Webbased Scientific Communication Skill in Science Education Seminar Course. Jurnal Pendidikan IPA Indonesia, 6(1), 123-129.

Tosto, M. G., Asbury, K., Mazzocco, M. M. M., Petrill, S. A., \& Kovas, Y. (2016). From classroom environment to mathematics achievement: The mediating role of self-perceived ability and subject interest. Learning and Individual Differences.

Djamarah, Syaiful Bahri. (2000). Teachers and Students in Eukative Interaction (Guru dan Anak Didik dalam Interaksi Eukatif). Jakarta: Rineka Cipta.

Elfanany, Burhan. (2013). Classroom Action Research (Penelitian Tindakan Kelas). Jogjakarta: Araska. 
Hamalik, Oemar. (1989). Media Education (Media Pendidikan). Bandung: PT Citra Aditya Bakti.

Hidayah, Istidan Sugiarto. (2004). Workshop I. Semarang: Mathematics Department FMIPA UNNES.

Jannah, Raodatul. (2011). Making Children Love Mathematics and Other Exacts (Membuat Anak Cinta Matematika dan Eksak Lainnya). Jogjakarta: DIVA Press.

Muhsetyo, Gatot. Et al. (2011). Primary Mathematics Learning Elementary Material: 1-9/PDGK4406/3 SKS (Materi Pokok Pembelajaran Matematika SD:1-9/PDGK4406/3 SKS). Jakarta: Open University. Sutikno, M.Sobry. (2014). Learning Methods $\mathcal{E}$ Models: Making Learning Processes More Variative, Active, Innovative, Effective, and Enjoyable (Metode $\mathbb{E}$ Model-model Pembelajaran: Menjadikan Proses Pembelajaran Lebih Variatif, Aktif, Inovatif, Efektif, dan Menyenangkan). Lombok: Holistica. 